\title{
Pengaruh Organizational Culture Terhadap Employee Performance Pada PT. X
}

\author{
Kho, Susan Raharja ${ }^{1}$ \\ Fakultas Psikologi Universitas Kristen Satya Wacana \\ Sutarto Wijono ${ }^{2}$ \\ Fakultas Psikologi Universitas Kristen Satya Wacana
}

\begin{abstract}
This research aims to find out organizational culture affects employee performance in the company. This research uses quantitative research conducted by jumping directly into the field. The sample used amounted to 37 people taken with non-probability sampling techniques. The study used scale in data collection. The variable scale of employee performance is taken from the scale of Robert and Jackson (2006) with statement items totaling 24. Organizational culture scale is taken from scale of Robbins (2002) with statement items totaling 23 items. Data analysis is done with the help of SPSS software. The results showed that the value of $R=$ 0.391; $p<0.05$ which means the influence given by Organizational culture as much as 39.1\% on Employee performance and the remaining $60.9 \%$ is influenced by other variables that are not in this study. That way, it can be known that organizational culture has a significant role in determining employee performance in PT. X.
\end{abstract}

Keywords: employee performance, Organizational culture

\begin{abstract}
Abstrak. Penelitian ini bertujuan mengetahui pengaruh organizational culture terhadap employee performance pada perusahaan. Penelitian ini menggunakan metode kuantitatif yang dilakukan dengan terjun langsung ke lapangan. Sampel yang digunakan berjumlah 37 orang yang diambil dengan teknik nonprobability sampling.Penelitian ini menggunakan skala dalam pengumpulan data. Skala variabel employee performance diambil dari skala Robert dan Jackson (2006) dengan item pernyataan berjumlah 24. Skala organizational culture diambil dari skala Robbins (2002) dengan item pernyataan berjumlah 23 item. Analisis data dilakukan dengan bantuan software SPSS. Hasil penelitian menunjukkan bahwa Nilai $R=0.391 ; F=22,506 ; p<0.05$ yang berarti pengaruh yang diberikan Organizational culture sebanyak 39,1\% terhadap Employee performance dan sisanya yaitu 60,9\% dipengaruhi oleh variabel lainnya yang tidak ada dalam penelitian ini. Dengan begitu, dapat diketahui bahwa organizational culture mempunyai peran yang signifikan dalam menentukan employee performance pada PT. X.
\end{abstract}

Kata kunci: Kinerja karyawan, Budaya Organisasi

\footnotetext{
${ }^{1}$ Korespondensi: Kho, Susan Raharja. Fakultas Psikologi Universitas Kristen Satya Wacana. J1. Diponegoro No.52-60, Salatiga, Kec. Sidorejo, Kota Salatiga, Jawa Tengah, 50711. Email: $\underline{\text { 802017170@student.uksw.edu }}$

${ }^{2}$ Korespondensi: Sutarto Wijono. Fakultas Psikologi Universitas Kristen Satya Wacana. Jl. Diponegoro No.52-60, Salatiga, Kec. Sidorejo, Kota Salatiga, Jawa Tengah, 50711. Email: sutarto.wijono@uksw.edu
} 
Perekonomian dunia saat ini sedang menghadapi persaingan global yang sangat intensif akibat teknologi informasi yang terus berkembang. Hal tersebut mengakibatkan tingginya dinamika yang memicu perubahan di berbagai kondisi lingkungan bisnis, sehingga disebut sebagai era Revolusi Industri 4.0 (Pratama \& Iryanti, 2020). Perubahan mendasar di era industri keempat ini adalah pesatnya peningkatan teknologi digital, yang berdampak besar pada berbagai sektor kehidupan masyarakat (Heri, 2019). Untuk menghadapi persaingan seperti ini, perusahaan harus mampu mempertahankan aset manusia, karena sumber daya ini terlibat langsung dengan perubahan tersebut. Selain itu, employee performance yang tinggi secara keseluruhan juga akan menciptakan perusahaan yang lebih produktif. Menurut Nahar, Indratjahyo, dan Guswandi (2020), penggunaan mesin dan teknologi yang digunakan dapat membantu perusahaan mengoptimalkan biaya operasi dengan mengurangi jam kerja dan karyawan. Namun terkadang di sisi lain, dengan kondisi penggunaan teknologi tinggi ini tidak cukup untuk mendukung pencapaian tujuan perusahaan. Salah satu penyebabnya adalah kinerja setiap pegawai yang mengoperasikan mesin atau teknologi ini tidak kunjung memenuhi target yang dibuat organisasi atau perusahaan. Penelitian terdahulu menunjukkan bahwa employee performance yang tinggi akan menempatkan perusahaan pada posisi daya saing yang tinggi dalam jangka panjang (Farchan, 2018).

Mengenai employee performance, disebutkan bahwa kinerja merupakan segala hal yang karyawan kerjakan maupun tidak kerjakan. Indikator dari employee performance adalah quantity, quality, reliability, presence, ability to work together (Robert, 2001). Menurut Timple (dalam Kosasih, 2014) employee performance dapat dipengaruhi oleh banyak hal meliputi faktor intern dan ekstern. Faktor intern yang terdapat pengaruhnya terhadap kinerja itu asalnya dari dalam diri karyawan, yang meliputi: job satisfaction, work motivation and organizational commitment sedangkan faktor-faktor eksternal yang ada pengaruhnya dengan kinerja karyawan berasal dari lingkungan kerja, yaitu: organizational culture, leadership style dan organizational climate.

Terdapat beberapa fenomena yang terjadi di PT. X, perusahaan dalam sektor industri kuliner yang besar di Indonesia dan telah berdiri sejak Agustus 1995. Penulis menggali informasi terkait employee performance divisi lingkungan pada PT. X tersebut. Dalam kurun waktu tertentu, penulis kemudian melakukan observasi dan wawancara dengan 6 orang karyawan divisi. Penulis menemukan ada 3 orang yang menunjukkan bahwa output pekerjaan yang menurun (kuantitas), menurunnya kualitas pekerjaan, kurang dapat diandalkan untuk mencapai target di saat permintaan produksi tinggi, tingginya tingkat ketidakhadiran (absensi), hingga kurangnya kemampuan karyawan untuk bekerja sama satu dengan lainnya. Sebagaimana penjelasan kepala divisi juga mengungkapkan bahwa tingkat ketidakhadiran karyawan di pos-posnya menurun dalam beberapa bulan terakhir. Ketidakhadiran karyawan ini tentunya mempengaruhi kuantitas dan kualitas hasil pekerjaan secara keseluruhan, sehingga perusahaan tidak dapat mencapai hasil yang ditargetkan. Tidak hanya itu, beberapa ruang kerja yang sepi juga ternyata telah menyebabkan menurunnya disiplin karyawan dalam melakukan pekerjaannya. Sebanyak 3 orang karyawan lainnya juga menjelaskan bahwa selama beberapa bulan terakhir, karyawan merasa kurang menikmati pekerjaannya karena teman-teman mereka secara bergantian melakukan absen, bekerja sebisanya, sehingga banyak permintaan produksi 
yang tidak terakomodasi. Menurut Stephen dan Stephen (2016) sangat sulit bagi sebuah perusahaan untuk memulai, bertahan, menstabilkan, dan unggul dalam bisnis. Perusahaan yang memiliki keunggulan dari kompetitor mereka dan didukung oleh tenaga kerja yang berdedikasi, dapat tetap menjadi yang terdepan di pasar. Employee performance merupakan salah satu faktor terpenting bagi kemajuan perusahaan, sehingga keberhasilan perusahaan membutuhkan koordinasi yang erat dari karyawan pada pekerjaannya masing-masing. Atas dasar beberapa fenomena tersebut dapat disimpulkan sementara bahwa ada masalah yang terjadi di PT. X, khususnya terkait employee performance.

Oleh sebab itu, penelitian tentang employee performance penting diteliti. Sebagaimana beberapa penelitian juga mengemukakan bahwa variabel ini juga menjadi sinyal penting bagi penurunan atau kenaikan kinerja perusahaan secara keseluruhan (Setyawan, 2018). Dalam hal ini, penurunan employee performance terkadang terjadi bukan karena gaji yang besar atau peluang karir di perusahaan, tetapi lebih kepada tidak diikutsertakannya karyawan untuk terlibat langsung dalam tujuan besar perusahaan. Hal tersebut kemudian berujung pada sikap karyawan yang tidak memiliki keyakinan kolektif, nilai, sikap, kepercayaan, dan keterbukaan atau takut tidak akan penghargaan moral, atau takut menghadapi situasi baru di lingkungan pekerjaan lamanya (Sinaga, Asmawi, Madhakomala, \& Suratman, 2018). Sehingga karyawan yang memiliki keinginan untuk menyelesaikan pekerjaannya dengan tepat waktu akan menurun, maka dari itu karyawan lebih sering lebih lambat dalam bekerja. Oleh karena itu, meningkatkan employee performance merupakan tugas penting bagi perusahaan yang dampaknya tidak hanya terlihat dari peningkatan produksi, tetapi juga meningkatnya kepuasan pelanggan secara keseluruhan.

Setiap karyawan yang berusaha selalu meningkatkan kinerjanya akan melaksanakan segala tugas yang menjadi kewajiban yang telah dibebankan kepadanya, baik secara kualitas maupun kuantitas, dan sesuai waktu produksi yang ditentukan oleh perusahaan (Kawiana, Dewi, Martini, \& Suardana, 2018). Sebaliknya, menurunnya employee performance akan menghasilkan kerendahan pada keinginan karyawan agar bisa tepat waktu dalam penyelesaian tugasnya yang berakibat pada terlambatnya karyawan tersebut saat melaporkan hasil pekerjaannya pada pimpinan (Jufrizen, 2017). Terdapat hasil penelitian bahwa penurunan employee performance seringkali terjadi bukan karena gaji yang besar atau peluang karir di perusahaan, tetapi karena ada faktor lain, diantaranya seperti budaya organisasi (Oktarina, Marnis, \& Suarman, 2019). Organizational culture adalah norma, nilai, dan keyakinan dimana pegawai harus berperilaku dalam perusahaan, mengenai segala hal yang dilakukannya di perusahaan dan termasuk faktor penting dalam keberhasilan dan pertumbuhan organisasi (Mohsen, Neyazi, \& Ebtekar 2020).

Organizational culture merupakan persepsi karyawan ataupun anggotanya atau sebuah sistem yang berasal dari makna yang dianut bersama-sama (Robbins, 2002). Budaya merupakan sistem makna dan sebuah kepercayaan dianut serentak oleh para anggota organisasi yang menunjukkan mayoritas cara dalam bertindak kepada karyawan lain dan orang diluar perusahaan. Menurut Sutrisno (2010) organizational culture merupakan sebuah sistem nilai-nilai, atau norma-norma, segala asumsi dan nilai-nilai yang dilaksanakan oleh seluruh karyawan tanpa terkecuali karena hal tersebut 
merupakan peraturan yang ada untuk membantu problem solving atas segala permasalahan dalam organisasi. Budaya organisasi memuat beberapa karakteristik di dalam suatu perusahaan yang berjumlah dua belas karakteristik diantaranya leadership, innovation, supervision, dan beberapa hal lain seperti inisiasi, toleransi, arah, integrasi, dukungan manajemen, toleransi terhadap konflik, identitas, kompensasi, komunikasi.

Organizational culture yang baik akan membuat karyawan merasa selalu dihormati, sehingga mau mengekspresikan mereka dalam mencapai tujuan perusahaan (Muis, Jufrizen, \& Fahmi, 2018). Organizational culture merupakan kunci bagi karyawan untuk beradaptasi terhadap perubahan lingkungan industri dan memungkinkan terjadinya integrasi internal dalam menghadapi perubahan tersebut (Joseph \& Kibera, 2019). Oleh karena itu, employee performance akan dapat lebih dipahami dengan menganalisis organizational culture, karena perusahaan menanggapi keadaan yang berubah berdasarkan budaya yang tanpa sadar dilakukan oleh seluruh anggota organisasi (Ariyanto \& Munir, 2019).

Pengaruh antara organizational culture dan employee performance telah menjadi salah satu subjek penelitian yang banyak diteliti. Fahlevi, Muharam, dan Hayati (2017) menemukan bahwa organizational culture mempengaruhi employee performance dalam konteks perusahaan properti. Di sisi lain, penelitian Hidayat, Chandra, dan Panjaitan (2018) menyimpulkan motivasi kerja dan gaya kepemimpinan mempengaruhi employee performance, namun organizational culture tidak berpengaruh terhadap employee performance dalam konteks industri pelayanan. Bagi sebuah perusahaan, sangat penting untuk memahami kekuatan budaya dan dampaknya terhadap kinerja perusahaan. Jika dibandingkan penelitian yang ada sebelumnya, perbedaan yang paling mendasar adalah responden penelitian yang dipilih dan variabel yang diteliti. Objek yang diteliti dalam penelitian ini merupakan karyawan pada perusahaan yang memproduksi berbagai varian minuman serbuk, dengan variabel yang hanya mengkonsentrasikan pada faktor organizational culture dalam pengaruhnya terhadap employee performance pada PT. X. Sehingga hipotesis yang diajukan pada penelitian ini yaitu organizational culture memiliki pengaruh signifikan terhadap employee performance pada PT. X. Tujuan penelitian ini adalah untuk mengetahui pengaruh organizational culture terhadap employee performance pada PT. X.

\section{METODE}

Penelitian ini menggunakan penelitian kuantitatif yang memberi penekanan statistik dalam analisis dan pengolahan data-data numerik. Dalam penelitian ini digunakan metode penelitian lapangan yang menggunakan berbagai informasi dan data yang ditemukan langsung di lapangan (Abdullah, 2015). Sampel yang digunakan dalam penelitian ini berjumlah 37 orang yang jumlahnya sama dengan populasi dan diambil dari keseluruhan partisipan pada anggota divisi lingkungan PT. X menggunakan teknik nonprobability sampling dengan penentuan sampel dari seluruh populasi yang digunakan sebagai sampel. Penelitian ini menggunakan angket/ kuesioner dalam pengumpulan data. Kuesioner termasuk dalam teknik untuk mengumpulkan data penelitian yang diberikan kepada responden dengan pemberian beberapa pertanyaan atau pernyataan (Sugiyono, 2018). Dalam pengukuran variabel yang diteliti, menggunakan skala likert yang terdiri dari dua pernyataan favorable dan unfavorable. Instrumen penelitian berupa angket/ 
kuesioner diberikan kepada subjek dalam bahasa Indonesia.

Skala penelitian variabel employee performance menggunakan skala yang dikemukakan oleh Robert dan Jackson (2006), didalamnya terdiri dari 5 indikator, yaitu: quantity, quality, reliability, presence, ability to work together. Skala ini berisi 24 item, yang telah dibagi dalam 2 kelompok pernyataan yaitu favorable dan unfavorable. Skala penelitian variabel organizational culture menggunakan skala yang dikemukakan oleh Robbins (2002), yang terdiri dari 10 faktor, yaitu: innovation and risk taking (inovasi \& pengambilan resiko), leadership (kepemimpinan), integrity (integritas), dukungan dalam manajemen, mengawasi, identitas diri, hadiah, penerimaan atas problem, dan komunikasi. Skala ini berisi 23 item, yang telah dibagi dalam 2 kelompok pernyataan yaitu favorable dan unfavorable.

Skala penelitian dari kedua variabel yang digunakan dilakukan uji reliabilitas terlebih dahulu untuk melakukan penentuan kepercayaan dan keandalan sebuah alat ukur yang digunakan dengan menggunakan standar keandalan dengan nilai berkisar antara nol sampai satu yaitu Cronbach's Alpha yang memiliki nilai keandalan minimum sebesar 0.70 (Hair, Black, Babin, Anderson, \& Tatham, 2006). Pada variabel employee performance tersisa 22 item dari total 24 item dengan skor Cronbach Alpha sebesar $0,888>0,70$, sedangkan pada variabel organizational culture tersisa 18 item dari total 23 item dengan skor Cronbach Alpha sebesar $0,838>0,70$.

Teknik analisis data menggunakan pengolahan statistik dengan software SPSS 21 for windows sebagai aplikasi bantu pengujian data yang kemudian terlebih dahulu melakukan pengujian validitas dan reliabilitas alat ukur kedua variabel (employee performance dan organizational culture), uji asumsi klasik yang meliputi uji normalitas Kolmogorov-smirnov, uji linearitas, uji multikolinearitas, uji heteroskedastisitas, dan selanjutnya pengujian hipotesis menggunakan regresi linear.

\section{HASIL DAN PEMBAHASAN}

\section{Analisis deskriptif}

Penelitian dilakukan dengan memberikan skala penelitian pada 37 subjek di departemen lingkungan pada PT. X. Hasil analisis deskriptif dan uji statistik penelitian serta hipotesis diuji dengan software SPSS 25 for windows. Hasil analisis deskriptif pada variabel employee performance disusun dengan menggunakan empat kategori yaitu sangat tinggi, tinggi, rendah dan sangat rendah. Dari hasil penelitian yang telah didapatkan, employee performance pada karyawan Departemen A di PT. X yang termasuk dalam kategori "Sangat Rendah" sebanyak $2,7 \%$ atau 1 orang, dan yang termasuk dalam kategori "Rendah" sebanyak $0 \%$ atau tidak ada sama sekali, dan yang termasuk dalam kategori "Tinggi" sebanyak $37,8 \%$ atau 14 orang, sedangkan yang termasuk dalam kategori "Sangat Tinggi" sebanyak 59,5\% atau 22 orang. Secara umum employee performance pada karyawan departemen lingkungan di PT. X berada dalam kategori sangat tinggi $(59,5 \%)$. Sehingga dapat disimpulkan, banyak karyawan yang terpengaruh dalam performa pekerjaannya.

Terdapat beberapa kemungkinan dari hasil penelitian ini. Pertama, employee performance yang baik pada sebagian besar karyawan merupakan hasil pengaruh dari organizational culture yang ditanamkan oleh perusahaan pada karyawannya. Hal ini didukung oleh pernyataan Kawiana, Dewi, Martini, dan Suardana (2018) yang menyatakan bahwa 
peningkatan employee performance merupakan tugas penting bagi perusahaan yang berdampak pada peningkatan produksi serta kepuasan pelanggan. Setiap karyawan yang berusaha selalu meningkatkan kinerjanya akan melaksanakan segala tugas yang menjadi kewajiban yang telah dibebankan kepadanya, baik kualitasnya maupun kuantitasnya serta waktu yang diberikan oleh perusahaan. Selain itu, menurut Jufrizen (2017) yang menjelaskan mengenai hal yang akan terjadi sebaliknya, apabila karyawan memiliki kinerja yang rendah, tentu hasil pekerjaan yang dilakukan tidak akan memuaskan dan bahkan tidak memenuhi target yang ditetapkan oleh perusahaan. Hasil dalam penelitian ini juga didukung oleh pernyataan Kawiana, Dewi, Martini, dan Suardana (2018) yang menunjukan bahwa organizational culture berpengaruh secara signifikan terhadap employee performance.

Tabel 1. Analisis deskriptif variabel employee performance

\begin{tabular}{llll}
\hline Kategori & Interval & Frekuensi & Persentase \\
\hline $\begin{array}{l}\text { Sangat } \\
\text { tinggi }\end{array}$ & $73 \geq \mathrm{x}<89$ & 22 & 59,5 \\
Tinggi & $56 \geq \mathrm{x}<72$ & 14 & 37,8 \\
Rendah & $39 \geq \mathrm{x}<55$ & 0 & 0 \\
Sangat & $22 \geq \mathrm{x}<38$ & 1 & 2.7 \\
rendah & & & \\
\hline Total & & 37 & 100 \\
\hline
\end{tabular}

Sedangkan hasil analisis deskriptif pada variabel organizational culture disusun dengan menggunakan empat kategori yaitu sangat tinggi, tinggi, rendah dan sangat rendah. Dari hasil pengujian yang dilakukan, organizational culture pada karyawan Departemen A di PT. X dengan kategori "Sangat Rendah" jumlahnya 5,4\% atau 2 orang, dan dengan kategori " Rendah" jumlahnya $2,7 \%$ atau 1 orang, dan dengan kategori "Tinggi" jumlahnya $81,1 \%$ atau 30 orang, sedangkan kategori "Sangat Tinggi" jumlahnya $10,8 \%$ atau 4 orang. Secara umum organizational culture pada karyawan departemen lingkungan di PT. X berada dalam kategori tinggi $(81,1 \%)$. Sehingga dapat disimpulkan bahwa organizational culture berpengaruh secara signifikan pada karyawan departemen lingkungan di PT. $\mathrm{X}$.

Terdapat beberapa kemungkinan dari hasil penelitian ini. Pertama, sebagian besar karyawan menganggap bahwa budaya organisasi yang ada di PT. X telah diimplementasikan dengan baik oleh para karyawan sehingga mereka dapat mencapai employee performance yang baik dan mencapai hasil yang maksimal bagi perusahaan. Kedua, Sebagian karyawan telah mematuhi budaya organisasi sehingga setiap karyawan dapat menerapkan nilai-nilai organizational culture pada pelaksanaan tugas dan tanggung jawab mereka. Dari dua kemungkinan ini didukung oleh Joseph dan Kibera (2019), yang menyatakan bahwa organizational culture merupakan kunci bagi karyawan untuk beradaptasi terhadap perubahan lingkungan industri dan memungkinkan terjadinya integrasi internal dalam menjalankan tugas dan tanggung jawab serta menghadapi tantangan dunia pekerjaan. Dalam kinerja karyawan didasari oleh organizational culture yang dipegang oleh perusahaan. Organizational culture yang baik akan membuat karyawan merasa selalu dihormati, sehingga mau mengekspresikan mereka dalam mencapai tujuan perusahaan (Muis, Jufrizen, \& Fahmi, 2018). Selain itu juga didukung oleh temuan Pawirosumarto, Sarjana, dan Gunawan (2017) yang menyatakan bahwa organizational culture berpengaruh 
terhadap employee performance.

Tabel 2. Analisis deskriptif variabel organizational culture

\begin{tabular}{llll}
\hline Kategori & Interval & Frekuensi & Persentase \\
\hline $\begin{array}{l}\text { Sangat } \\
\text { tinggi }\end{array}$ & $60 \geq \mathrm{x}<73$ & 4 & 10,8 \\
Tinggi & $46 \geq \mathrm{x}<59$ & 30 & 81,1 \\
Rendah & $32 \geq \mathrm{x}<45$ & 1 & 2,7 \\
$\begin{array}{l}\text { Sangat } \\
\text { rendah }\end{array}$ & $18 \geq \mathrm{x}<31$ & 2 & 5,4 \\
\hline Total & & 37 & 100 \\
\hline
\end{tabular}

\section{Uji normalitas}

Pengujian distribusi data dalam penelitian ini menggunakan uji normalitas yang perhitungannya dilakukan dengan menggunakan uji one-sample kolmogorov-smirnov test. Variabel organizational culture memiliki $P$ value. $0,106 \quad(\mathrm{p}>0,05)$ dan variabel employee performance memiliki skor signifikansi $0,726(\mathrm{p}>0,05)$. Hasil yang didapatkan dalam pengujian normalitas uji one-sample kolmogorov-smirnov test. Menunjukkan kedua variabel penelitian memiliki distribusi yang normal.

Tabel 3. Tabel kolmogorov-smirnov

\begin{tabular}{lccc}
\hline Variabel & K - S & Sig. & Status \\
\hline $\begin{array}{l}\text { Employee } \\
\text { Performance }\end{array}$ & 0.691 & 0.726 & Normal \\
$\begin{array}{l}\text { Organizational } \\
\text { Culture }\end{array}$ & 1.212 & 0.106 & Normal \\
\end{tabular}

\section{Uji linearitas}

Uji linearitas dilakukan dengan tujuan untuk mengetahui hubungan kedua variabel yang diteliti apakah linier secara signifikan atau tidak. Uji linearitas ini dilakukan dengan menggunakan software SPSS 21.0 menggunakan test for linearity. Berdasarkan $P$ Value 0,701 >0,05 dapat diketahui bahwa variabel organizational culture dan employee performance linear.

Tabel 4. Uji linearitas deviation from linearity

\begin{tabular}{ll}
\hline Variabel & Organizational Culture \\
\hline $\begin{array}{l}\text { Employee } \\
\text { Performance }\end{array}$ & 0.701 \\
Korelasi & Linier
\end{tabular}

\section{Uji multikolinearitas}

Dari hasil penelitian yang dilakukan dapat dilihat nilai Variance Inflation Factor (VIF) $1(\mathrm{p}<5)$, serta memiliki nilai tolerance value $1(\mathrm{p}>0,1)$ maka dapat disimpulkan bahwa tidak terjadi gejala multikolinearitas dalam penelitian ini.

Tabel 5. Tabel Tolerance dan VIF

\begin{tabular}{lll}
\hline \multirow{2}{*}{ Variabel } & \multicolumn{2}{l}{ Organizational Culture } \\
\cline { 2 - 3 } & Tolerance & VIF \\
\hline $\begin{array}{l}\text { Employee } \\
\text { Performance }\end{array}$ & 1.000 & 1.000 \\
Multikolineari- & $\begin{array}{l}\text { Tidak terjadi } \\
\text { multikolineari- } \\
\text { tas }\end{array}$ & $\begin{array}{l}\text { Tidak terjadi } \\
\text { multikolineari- } \\
\text { tas }\end{array}$ \\
\hline
\end{tabular}

\section{Uji heteroskedastisitas}

Gambar dibawah menunjukkan bahwa model regresi tidak membentuk sebuah pola yang jelas dan plot atau titik yang terdapat dalam gambar memiliki bentuk yang menyebar, dari gambar tersebut jelas bahwa tidak terjadi heteroskedastisitas atau disebut homoskedastisitas. Sehingga dapat disimpulkan bahwa tidak terjadi kesamaan antara penelitian ini dengan 
penelitian lainnya.

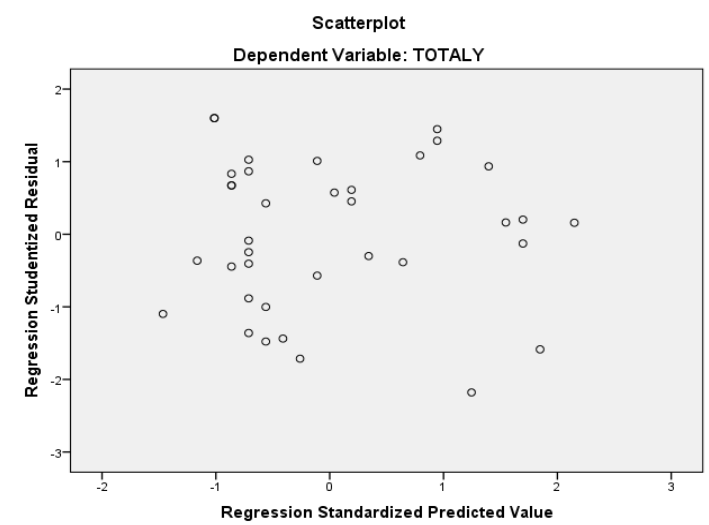

Gambar 1. Regression Standardized Predicted Value

\section{Uji hipotesis}

Pengujian hipotesis dilakukan guna melakukan pengujian pada variabel penelitian. Dari hasil penelitian diketahui bahwa nilai $\mathrm{R}$ sebesar 0,626 , nilai $\mathrm{R}$ menjelaskan nilai pengaruh antara variabel employee performance dan organizational culture sehingga besar pengaruh antara variabel employee performance dan organizational culture 0,626 yang artinya pengaruh kedua variabel cukup kuat. Sedangkan nilai $\mathrm{R}$ Square merupakan pengaruh yang diberikan variabel organizational culture terhadap variabel employee performance yaitu 39,1 yang artinya variabel organizational culture berpengaruh terhadap variabel employee performance sebesar $39,1 \%$ dan sisanya sebesar $60,9 \%$ dipengaruhi oleh variabel-variabel lainnya yang tidak ada dalam penelitian ini.

Tabel 6. Tabel $R$ Square

\begin{tabular}{lll}
\hline \multicolumn{2}{l}{ Model Summary } & \\
\hline Model & R & R Square \\
\hline 1 & 0.626 & 0.391 \\
\hline
\end{tabular}

Pada pengujian regresi ini dapat diketahui nilai $\mathrm{F}=22,506$ dengan $P$ Value $0.00<0.05$, sehingga dapat dibuat kesimpulan bahwa variable organizational culture berpengaruh secara signifikan terhadap variabel employee performance. Sehingga hipotesis penelitian ini yang menyatakan bahwa organizational culture memiliki pengaruh signifikan terhadap employee performance pada PT. X diterima.

Tabel 7. Tabel Anova

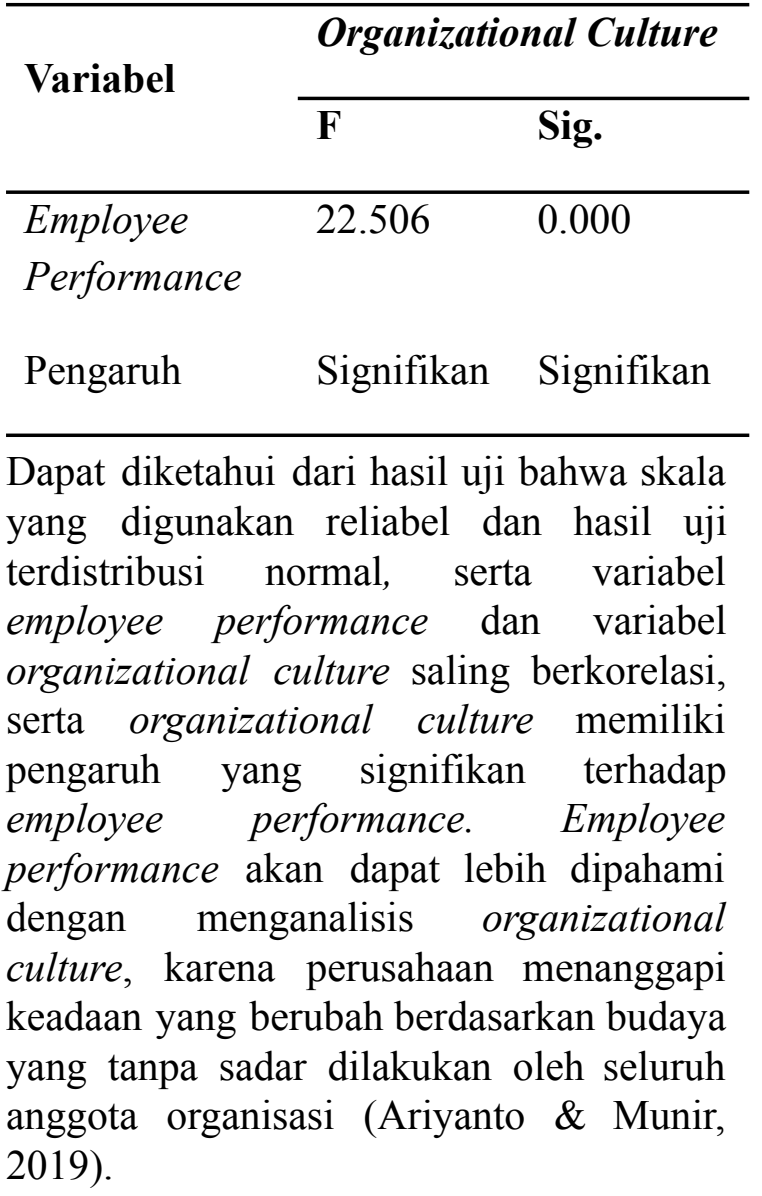

Terdapat penelitian yang mendukung hasil penelitian ini oleh Fahlevi, Muharam, dan Hayati (2017) menemukan bahwa organizational culture mempengaruhi employee performance dalam konteks perusahaan properti. Pada sektor pendidikan, Isa dan Ugheoke (2016) menjelaskan bahwa kinerja organizational culture memberi pengaruh yang kuat terhadap employee performance. Di sisi lain, penelitian Hidayat, Chandra, dan Panjaitan (2018) menyimpulkan motivasi kerja dan gaya kepemimpinan 
mempengaruhi employee performance, namun organizational culture tidak berpengaruh terhadap employee performance dalam konteks industri pelayanan. Sedangkan penelitian ini, meneliti apakah organizational culture mempengaruhi employee performance pada perusahaan produksi makanan \& minuman. Organizational culture mempengaruhi employee performance di PT. X. Dengan adanya peraturan seperti 5R, KKR Dialog yang mengedepankan kebersihan diri, alat, dan lokasi ini, sangat mempengaruhi cara kerja karyawan sehingga dapat menghasilkan produk yang berkualitas.

Sehingga dapat dibuat kesimpulan bahwa di dalam penelitian ini organizational culture memiliki pengaruh signifikan terhadap employee performance di PT. X dan hipotesis yang menyatakan bahwa organizational culture memiliki pengaruh yang signifikan terhadap employee performance pada PT. X diterima.

\section{KESIMPULAN}

Berdasarkan dari hasil pengujian dan analisis data, disimpulkan bahwa organizational culture berpengaruh secara signifikan terhadap employee performance pada karyawan Departemen A di PT. X. Hasil penelitian menunjukkan bahwa signifikansi sebesar $0.000<0.05$ yang berarti variabel organizational culture memiliki pengaruh signifikan terhadap variabel employee performance dengan skor $R$ Square sebesar 0.391 yang berarti variabel organizational culture berpengaruh terhadap variabel employee performance sebesar $39,1 \%$ dan sisanya sebesar 60,9 \% dipengaruhi oleh variabel-variabel lainnya yang tidak ada dalam penelitian ini. Dapat dilihat bahwa organizational culture merupakan faktor yang mempengaruhi employee performance, dimana apabila perusahaan memiliki employee performance yang baik, maka pasti merupakan pengaruh dari penanaman dan pengajaran organizational culture dari perusahaan tersebut. Namun apabila suatu perusahaan tidak menanamkan organizational culture pada karyawannya, maka akan mempengaruhi employee performance akan menurun.

\section{SARAN}

Diharapkan pihak perusahaan memberi kesempatan kepada para karyawan agar dapat menerapkan nilai - nilai organizational culture baik pada karyawan lama maupun karyawan baru agar employee performance. Hal tersebut dapat dilakukan melalui diskusi atau sharing. Bagi karyawan juga dapat menggunakan kesempatan untuk dapat mewujudkan nilai-nilai budaya perusahaan, dengan terus berusaha menerapkan nilai - nilai organizational culture pada setiap pekerjaan yang dilakukan, untuk dapat mencapai employee performance yg tinggi. Hal tersebut dapat melalui diskusi dan sharing bersama dengan karyawan atau atasan mereka.

\section{DAFTAR PUSTAKA}

Ariyanto., Maatpono., \& Munir, A. R. (2019). Pengaruh budaya organisasi, motivasi, dan komitmen organisasi terhadap kinerja pegawai: Studi kasus pada dinas pendidikan Provinsi Sulawesi Selatan. Hasanuddin Journal of Business Strategy, 1(3), 79-87.

Farchan, F. (2018). Strategi msdm sebuah cara menciptakan kinerja organisasi dalam mencapai keunggulan bersaing. Risalah, Jurnal Pendidikan dan Studi Islam, 4(1), 42-52.

Fahlevi, R. D., Muharam, H., \& Hayati, Y. H. (2017). Hubungan budaya organisasi dengan kinerja karyawan pada PT. Sejahtera Eka Graha. JOM, 1(1), 1-10. 
Hair, J. F., Black, W. C., Babin, B. J., Anderson, R. E., \& Tatham, R. L. (2006). Multivariate data analysis 6th Edition. N. $\mathrm{J}$ : Prentice Hall.

Heri, E.I. (2019). Tantangan Pengembangan sdm polri di era revolusi industri 4.0. Jurnal Ilmu Kepolisian, 13(2), 90-105.

Hidayat, R., Chandra, T., \& Panjaitan, H. P. (2018). Pengaruh budaya organisasi, motivasi kerja, dan gaya kepemimpinan terhadap kepuasan kerja dan kinerja karyawan pada spbu di Kabupaten Rokan Hilir. KURS, 3(2), 142-155.

Isa, M.F.M., \& Ugheoke, S.O. (2016). The influence of organizational culture on employees' performance: evidence from oman. Journal of Entrepreneurship and Business, 4(2), 1-12.

Joseph, O. O., \& Kibera, F. (2019). Organizational culture and performance: Evidence from microfinance institutions in Kenya. Sage Open, 9(1), 1-11.

Jufrizen. (2017). Efek moderasi etika kerja pada pengaruh kepemimpinan transformasional dan budaya organisasi terhadap kinerja karyawan. Jurnal Ekonomi Manajemen \& Bisnis, 18(2), 145-158.

Kawiana, I.G.P. Dewi, L.K.C., Martini, L.K.B., \& Suardana, I.B.R. (2018). The influence of organizational culture, employee satisfaction, personality, and organizational commitment towards employee performance. International Research Journal of Management, IT \& Social Sciences, 5(3), 35-45.

Kosasih, N. (2014). Analisis pengaruh budaya organisasi dan komitmen keorganisasian terhadap kinerja pegawai.
Jurnal dinamika manajemen, 2(3), 197-208.

Leithy, W.E. (2017). Organizational culture and organizational performance. International Journal of Economics \& Management Sciences, 6(4), 1-6.

Ma'ruf Abdullah. (2015). Metodologi penelitian kuantitatif. Yogyakarta: Aswaja Pressindo.

Mohsen, A., Neyazi, N., \& Ebtekar, S. (2020). The impact of organizational culture on employees performance: an overview. International Journal of Management (IJM), 11(8), 879-888..

Muis, M.R., Jufrizen , J., \& Fahmi, M. (2018). Pengaruh budaya organisasi dan komitmen organisasi terhadap kinerja karyawan. Jurnal Ekonomi \& Ekonomi Syariah, 1(1), 9-25.

Muryani. (2017). Food sector analysis in Indonesia: A social accounting matrix (sam) approach. JIEP, 17(2), 1412-2200.

Nahar, B., \& Indratjahyo, H. (2020). The influence of organizational culture and organizational commitment to employee performance through job satisfaction at PT. Seoilindo Primatama Bekasi. International Journal of Business and Social Science Research, 1(1), 7-16.

Oberfoll, K., Adame, M.E.C., \& Garcia, M.L.S. (2018). Relationship between organizational culture and performance among German multinational companies in Mexico. Journal of Business Universidad del Pacífico (Lima, Peru), 10(2), 24-47.

Oktarina, F. Marnis., \& Suarman. (2019). The Effect of organizational culture and competence on motivation and performance in the hr department of PT. 
Chevron Pacific Indonesia Pekanbaru Riau. Procuratio, 7(1), 98-113.

Pawirosumarto, S., Sarjana, P.K., \& Gunawan, R. (2017). The effect of work environment, leadership style, and organizational culture towards job satisfaction and its implication towards employee performance in parador hotels and resorts, Indonesia. International Journal of Law and Management, 59(6), 1337-1358.

Pratama, H.A., \& Iryanti, H.D. (2020). Transformasi sdm dalam menghadapi tantangan revolusi 4.0 di sektor kepelabuhan. Majalah Ilmiah Bahari Jogja, 18(1), 71-80.

Rijanto, A., \& Mukaram. (2018). Pengaruh budaya organisasi terhadap kinerja karyawan: Studi di divisi account executive PT. Agrodana Futures. Jurnal Riset Bisnis dan Investasi, 4(2), 35-47.

Robbins SP. (2002) . Prinsip- prinsip perilaku organisasi (5th ed.). Jakarta: Erlangga.

Robert, L.M. (2001). Human resources management. Jakarta : Salemba Empat.

Robert, L.M., \& Jackson, J.H. (2006). Manajemen sumber daya manusia (10th ed.). Jakarta : Salemba Empat.

Rosvita, V., Setyowati, E., \& Fanani, Z. (2017). Pengaruh budaya organisasi terhadap kinerja karyawan. Indonesia Jurnal Farmasi, 2(1), 14-20.

Sinaga, H.G., Asmawi, M., Madhakomala, R., \& Suratman, A. (2018). Effect of change in management, organizational culture and transformational leadership on employee performance PT. Adhya Tirta Batam. International Review of Management and Marketing, 8(6), 15-23.
Stephen, E. N., \& Stephen, E. A. (2016). Organizational culture and its impact on employee performance and job satisfaction: A case study of Niger Delta University, Amassoma. Higher Education of Social Science, 11 (5), 36-45.

Setyawan, A. (2018). Analisis faktor-faktor yang mempengaruhi kinerja karyawan (studi kasus pada tiga perusahaan fabrikasi lepas pantai di batam dan karimun). Journal of Accounting and Management Innovation, 2(1), 67-89.

Sugiyono. (2018). Metode Penelitian kombinasi (mixed methods). Bandung: CV Alfabeta

Sutrisno E. (2010). Budaya organisasi. Jakarta: Kencana Prenada Media Group.

Yudiani, E. (2017). Work engagement Karyawan PT. Bukit Asam Persero ditinjau dari spiritualitas. Jurnal Psikologi Islami, $3(1), 21-3$ 